\title{
Amusing Abusers and Humourless Survivors: Analysing the Role of Comedy in Media Representations of Sexual Violence
}

\section{Bethany Rose Lamont}

University of the Arts London. London, UK. Email: bethanyroselamont[at]yahoo.co.uk

\begin{abstract}
This article reflects on the importance of comedy when considering media engagements with sexual abuse themes. This approach is informed by how closely the study of humour is rooted in the analysis of power relations, with comic theorists, both historical and contemporary, grounding the work. The comic figures of both the child sex (CS) abuser and the sexual violence survivor are first identified, before exploring what exactly about these tropes evoke laughter, and what this means for wider conceptions of interpersonal abuse and victimology.
\end{abstract}

In analysing examples of CS abuser themed British and American comedy, animated adult comedies such as Family Guy (1999-present) and Monkey Dust (2003-2005) are considered in the context of early 2000s anxieties towards the suburban dirty old man and online child safety. In the case of the sexual violence survivor, Saturday Night Live's 1993 'Is It Date Rape?' sketch is considered within the context of 1990s anxieties regarding feminist campus politics, and is paralleled to the mid-2010s media panic surrounding British and American university students and trigger warnings through examples including The Simpson's 2017 'Caper Chase' episode and early to mid-2010s online academic polemics on the humourless feminist, such as Mark Fisher's 'Exiting The Vampire Castle' (2013) and Jack Halberstam's 'You are Triggering Me!' (2014). The article concludes by considering the changing consensuses for sexual violence themed humour in the Me Too era through the 2018 episode of It's Always Sunny in Philadelphia (2005-present) 'Times Up For The Gang.'

\section{Keywords}

Monkey Dust; Family Guy; Saturday Night Live; Friends; It's Always Sunny in Philadelphia; Comedy Studies; Trauma Theory; Television Comedy; Childhood Sexual Abuse; Rape Jokes; Feminist Media Studies

\footnotetext{
This work is licensed under a Creative Commons «Attribution» 4.0 International License
} 


\title{
Забавные обидчики и выжившие без юмора: анализ роли комедии в репрезентациях сексуального насилия в СМИ
}

\author{
Ламонт Бетани Роуз \\ Лондонский Университет Искусств. Лондон, Великобритания. \\ Email: bethanyroselamont[at]yahoo.co.uk
}

\section{Аннотация}

Эта статья посвящена важной роли комического при рассмотрении работы СМИ с темами сексуального насилия. Данный подход сформирован тем, насколько глубоко изучение юмора уходит корнями в изучение властных отношений, и как теоретики комиксов, исторические и современные, вносят свой вклад в этот анализ. Прежде чем исследовать, что именно в этих образах вызывает смех, и что это означает для более широких представлений о сексуальном насилии, сначала идентифицируются персонажи комиксов: как детского сексуального абьюзера (CS), так и пережившего сексуальное насилие.

При анализе примеров британской и американской комедии на тему CS-абьюзера рассматриваются анимационные комедии для взрослых, такие как Family Guy (1999-по настоящее время) и Monkey Dust (2003-2005), в контексте тревог начала 2000-х, связанных с грязным стариком с окраин и безопасностью ребенка в интернете. В случае с пережившим сексуальное насилие зарисовка «Is It Date Rape?» 1993 года в «Saturday Night Live» рассматривается в контексте тревог 1990-х годов, связанных с политикой феминистского кампуса, и проводится параллель с паникой в СМИ середины 2010-х годов, окружавшей британских и американских студентов университетов, и предупреждений с помощью примеров, в том числе эпизода из «Симпсонов» 2017 г. «Погоня за капюшоном», а также академической полемики о лишенных юмора феминистках в интернете с начала до середины 2010-х годов, таких как «Exiting The Vampire Castle» Марка Фишера (2013) и «You are Triggering Мe!» Джека Халберштама (2014). В заключении статьи рассматривается изменение консенсуса в отношении юмора на тему сексуального насилия в эпоху «Ме Тоо» в эпизоде «Times Up For The Gang» 2018 года в «Always Sunny in Philadelphia» (с 2005 г. по настоящее время).

\section{Ключевые слова}

«Monkey Dust»; «Гриффины»; «Saturday Night Live»; «Друзья»; «Always Sunny in Philadelphia»; комедийные исследования; теория травм; телевизионные комедии; сексуальное насилие в детстве; анекдоты об изнасилованиях; феминистские исследования СМИ

Это произведение доступно по лицензии Creative Commons «Attribution» («Атрибуция») 4.0 Всемирная 


\section{Introduction}

The comic genre serves as an enduring testament to cultural and social engagements with the murky borders between the acceptable and the obscene, illuminating cultural archetypes that in polite conversation are often out of sight. Here comedy can permit the joke teller to speak about unspeakable subjects, and transcend expectations of pity and sentimentality to find humour in others suffering. But whose pain produces laughter and why? In this article, late $20^{\text {th }}$ century to 2010s British and American screen comedy inspired by the taboo subject of child sexual abuse (CSA), paedophilia and rape will serve as the central focus. This is with the objective of asking: how can laughter be found in such acts of violence? And what can this tell us about how archetypical characters of sexual violence are conceived in popular culture?

This cast of characters analysed in this article as follows: First, the dirty old man of white American suburbia, found in Family Guy (1999-present). Next, the chat room predator that dominated online child safety discourse of the 1990s and 2000s, identified in Monkey Dust (2003-2005). Following this, we move onto the enduring trope of the humourless young feminist student, whose diverse examples across the decades include Saturday Night Live's 1993 'Is It Date Rape?' sketch, The Simpson's 'Caper Chase' episode (2017) and online, academic polemics by scholars such Mark Fisher (2013) and Jack Halberstam's (2014). Finally, the article concludes with the comic figure of the white, male, wealthy American rapist, found in the character of Dennis Reynolds of It's Always Sunny in Philadelphia (2005-present), a long running American sitcom, that gestures towards cultural shifts in sexual violence humour in response to the Me Too movement.

\section{Methodology}

Examples in this study are limited within a late 20th century and early $21^{\text {st }}$ century American and British context, to ensure the analysis is contained to contextual archetypes of this cultural era, such as the dirty old man of white American suburbia, the chatroom predator and the hysterical survivor of the American and British university campus. These tropes were selected particularly due to their prevalence in moral panics and cultural conflicts within this particular time period, whilst the screen comedy examples analysed offer a paradigmatic reflection of these tropes to a large-scale audience.

Within this study, examples were contained to mainstream screen media from major broadcasters (for instance Fox, $\mathrm{ABC}$ ) and does not extend to digital media platforms such as YouTube. However, they are complemented by contexts of feminist comedy, and academic debates surrounding the subjects of trauma and comedy within the early to mid-2010s. The audience reach for these selected examples were considerable and reflect their popularity within their particular place and time. 
For example, the Friends episode analysed premiered to an American audience of 22.64 million in 2004 (ABC, 2004), whilst Family Guy at the peak of its popularity in the 2000s viewership ranged from 9.93-11.85 million viewers for a season premiere. Whilst, The Simpsons popularity has flagged from its 1990s peak, the cited episode Caper Chase received 2.13 million viewers.

Such examples are accompanied by darkly comic cult comedy shows such as It's Always Sunny in Philadephia (IASIP) and Monkey Dust. Though these examples did not garner the same large scale of viewing figures numbers, they do offer an insight into the genre of black humour and shock humour during their selected time period. For example, Monkey Dust provides a unique translation of early 2000s British CSA narratives in comic sketch show form. Whilst, IASIP's status (as of December 2020) as the longest running American live action comedy, provides an insight into shifting audience sensibilities for intentionally offensive humour. However, the analysed examples should not be understood as either universally humorous, well-regarded or representative of the shifting codes of consent, childhood, comedy and the taboo across nations, histories and languages. Rather they simply represent one incarnation of how the subject of sexual violence may be reimagined and retold through comedy during a selected cultural context, medium and time period.

The article's methodology consists of an informed interdisciplinary approach, combining comedy studies, legal history, media studies and queer feminist theory, coupled with a close reading method, which examines a small number of humorous cultural representations of the CS abuser and the sexual violence survivor. Due to the sensitive nature and complex intersections of CSA and sexual violence it is necessary to go beyond a single study approach to understanding the cultural manifestations of this criminal act. For, quite simply, when it comes to such a subject there is no single answer.

The concept of interdisciplinary trauma theory, coupled with a close reading of cultural representations of trauma, was spearheaded by queer theorist Ann Cvetkovich in her 2003 study An Archive of Feelings: Trauma, Sexuality and Lesbian Public Spaces, and forms the foundation of this article's methodology. Cvetkovich proposes that in framing trauma theory as a process of cultural analysis, that is "defined culturally rather than clinically", the study becomes inherently interdisciplinary due to its subsequent focus on "the public cultures created around traumatic events." (Cvetkovich, 2003, p. 18)

The examples of screen comedy provided here are selected with the intention of exploring the complexity of mass media engagement within such a provocative theme. This is approached within the early 20th century philosopher Henri Bergson's argument that "the comic does not exist outside of the pale of what is strictly human." (Bergson, 1911, p. 2) To divide audience engagement with sexual abuse representations into survivors and abusers is too simplistic an approach for such a complex subject. By bringing in the subject of broader cultural engagements 
with sexual violence, beyond the abuser/survivor dichotomy, this article examines the wider influence mass media has on exploring, subverting and transmitting ideas surrounding the subject of sexual violence.

The decision to focus on comic representations, and receptions, of sexual violence narratives is informed by how closely the study of humour is rooted in the study of power relations and audience interaction. In earlier humour scholarship, this has been identified in connecting joke telling to the struggle between adult and child and between predator and prey, as illustrated in the work of Sigmund Freud (1905) and Gershon Legman (1968), and is reflected in the dynamic humour studies research surrounding subjects such as the rape joke, playground humour and countercultural comedy (Thompson, 2016; Medjesky, 2016; Stott, 2014; Krefting, 2014). This critically intersects with feminist scholarship, as throughout the history of humour studies, a rigorous analysis of power dynamics and an awareness of intracommunity interaction shine through (Douglas, 2015). Thus, making both the genre of humour, and the scholarship of humour studies, a powerful lens for addressing the subject of cultural engagements with sexual abuse themes. 'What is funny' is always about social construction and it is therefore necessary to contextualise the humour, and therefore the question is never 'why something is funny', but 'between whom is it funny'.

\section{Beyond a Joke? Unfunny humour, and the traumatic comic}

Comedy studies researchers, Dr Sharon Lockyer and Professor Michael Pickering identify certain subjects within humour "as overstepping the mark, as being beyond a joke" (Lockyer, Pickering, 2009, pp. 4, 5, 9). Under this lens, it would be reasonable to argue that humour surrounding rapists and CS abusers is inherently unfunny, because of the real harm and real victims such abusers cause and create. However, this is a premise I would disagree with: to say something is 'beyond a joke' is to assume that humour itself is a toothless endeavour. Rape and CSA in itself is not equivalent to other social issues such as racist, anti-Semitic, homophobic or misogynistic humour, though these social issues certainly shape who is most vulnerable to abuse, whose pain we find humorous and who is branded an abuser. But I would argue against the claim that just because a joke is hateful or evokes violence it ceases to be funny to its intended audience. To make this claim would be to equate funniness with goodness, or to assume that either terms are universally defined and agreed upon. Thus, comedy can function as an instrument of oppression" and "can assist the authorities in cementing their authority just as easily as it can undermine that authority." (McGowan, 2017, p. 163)

In 1944, Jean Paul Sartre warned of failing to take hateful humour seriously in his essay 'Anti-Semite and the Jew.' Stressing the importance of "never [believing] that anti-Semites are completely unaware of the absurdity of their replies", Sartre argued that rather the anti-Semites are "amusing themselves" as they "delight in acting in bad faith, since they seek not to persuade by sound argument but to 
intimidate and disconcert." (Sartre, 1948, p. 15) Whilst, Elaine Frantz Parsons, in her study of the Ku Klux Klan of the Reconstruction-Era emphasises how member "went to great lengths to stage their violence as comedy" (Frantz Parsons, 2005, p. 824).

For instance, in the 2018 Spike Lee film BlacKkKlansman, we follow the character of Flip Zimmerman, a Jewish undercover police officer looking to infiltrate and expose the Ku Klux Klan in 1970s Colorado. Zimmerman goes shooting with their members, engages and agrees with their hateful views on the Holocaust and antiBlack racism, and, perhaps most crucially, uses anti-Black and anti-Semitic humour in order to gain their trust. Of course, this humour is not funny to those who are not anti-Semites, anti-Black racists and white supremacists, because humour operates as the endorsement of shared insider cultural codes; it demonstrates who is a part of a particular group and under what conditions. But whether or not we find a particular joke funny does not neutralise its power or negate its position as a revealing cultural artefact of its particularly period and/or ideology.

Acknowledging the function of hurtful humour as humour does not deflect from the pain it causes, or from its signalling function towards a broader system of oppression. As the cultural historian Andrew Stott notes, "the question of how or why things come to be funny is determined by culture" (Stott, 2014, p. 8). This is because "jokes emerge from within the social framework and necessarily express the nature of their environment" (Stott, p. 10). Thus, we do not have to participate in or even endorse a particular strand of humour to recognise that such jokes are considered funny within their particular social context. Rather, in recognising the potentially traumatic nature of humour itself, we can better understand that the comic can exist as an endorsement, as well as a subversion, of the ruling order. This allows us to centre humour's function as a tool for expressing and exploring power dynamics, for both the powerful and the powerless, including but not limited to hateful and hurtful humour.

For as the professor of film studies, Todd McGowan reminds us, "one can find the joke [of racism, sexism, anti-Semitism and homophobia) politically and ethically reprehensible and nonetheless recognize the comedy." (McGowan, p. 127) In understanding comedy as a medium rather than a moral standing, we free up space to better analyse and understand the mechanics of comedy that create such disturbing examples of humour in the first place. (McGowan, 2017, p. 63) Here McGowan argues that such examples are not outliers but are rather built into "the specific structure of comedy itself" (McGowan, p. 127) because:

Comedy demands not only inclusion but also exclusion. Though comedy can include the object of the joke within the comic sphere, there must be someone excluded from that sphere, someone who doesn't get the joke or whom the joke necessarily marginalizes. If the joke did not exclude anyone, it would not be funny. This is the fate that all attempts to create an inoffensive humor necessarily suffer. Comedy that doesn't offend someone ceases to be comedy. (McGowan, p. 177) 
Moreover, to argue that because something is offensive it ceases to be funny fails to realise that many people find certain topics funny because they are offensive. This positions sexual abuse themed humour, such as the American screen comedy examples analysed, within the relief theory of comedy, where the very elements that make a subject fearful is also what makes it humorous (Morreall, 2009, pp. 15-23). Thus, we might laugh at CSA because it offends and upsets us, not in spite of this. As the Slovenian philosopher, Alenka Zupančič explains, "things that concern the very kernel of our being, can be watched and performed only as comedy, as an impersonal play with the object." (Zupančič, 2008, p. 182) This is not to endorse any and all jokes about CSA and other forms of sexual violence, or to suggest that I myself find the comic examples in this article particularly funny, but rather to explain and understand their prevalence within comedy through comic characters such as the dirty old man.

Furthermore, as humour is socially constructed, I do not analyse these examples with the anticipation that the reader will find them particularly funny either. It would be reasonable for a reader to find such crude examples of sexual abuse humour juvenile, offensive and deeply unfunny. Given "the immediacy of comedy", all examples are rooted deeply in the contexts of their time and place: American and British history of sketch comedy, sitcoms and animations from the 1990s, 2000s and mid-2010s during periods of moral panic in regards to the characters of the CS abuser and the sexual violence survivor. As a result of this limited nature these examples were selected not to signify a cultural or comic universalism, but rather because such crude humour provides a rich opportunity for analysing popular cultural engagements with the taboo issues of CSA and sexual violence, beyond the boundaries of respectability and so-called good taste.

However, rape and paedophilia themed humour do more than simply educate us about cultures and contexts of sexual violence, they expose the traumatic function of comedy itself. As McGowan argues "every comic moment is traumatic" (McGowan, p. 11) because:

Comedy forces us to confront, for instance, the failings of those whom we suppose to embody flawless authority, the inseparability of the enjoyment that comedy provides from its traumatic impact. There is no comedy without a jolt that potentially shatters the ground of our everyday lives. (McGowan, p. 180-181)

This returns us to the early history of comedy studies, where Sigmund Freud, in his study of hostile and obscene wit, Jokes and Their Relation to the Unconscious (1905) emphasised how closely the study of humour is rooted in the study of power relations, connecting joke telling to the struggle between adult and child and between predator and prey (Freud, 1905/2001, pp. 94, 102, 105). Gershon Legman's 1968 study Rationale of the Dirty Joke, then built upon Freud's theory of violent comedy to argue that "under the mask of humor our society allows infinite aggression." (Legman, 1968/2006, p. 11) It is such socially acceptable aggression that 
enables an audience to laugh at either rape victim or rapist, as well as to identify who wears these particular masks in this time in history.

The function of comedy as a mouthpiece for identifying and exploring themes of sexual violence can be more fully understood through Professor Roger Silverstone's 2006 research into creations of evil and Otherness in mass media. Silverstone emphasises "the profound centrality of play at the heart of media culture" (Silverstone, 2006, p. 125) when cultivating such "media narratives and popular demonology" (p. 65). As "there is no game without all participants" (p. 126) we can consider the ethics of audience participation when a viewer is held "morally culpable" $(128,108)$ for their laughter.

\section{Who is the Child Sex Abuser and Why Do We Laugh at Them?}

In identifying the comic character of the CS abuser, it is necessary to first recognise the conflation between cultural representations of the criminal figure who perpetuates such acts and the legal borders that outline its reality. This begs the question of whether the cultural model of child sexual abuse (CSA) storytelling and the reality of the legal system set up to prosecute harm towards minors overlap in the slightest. The cultural discrepancy between legal realities and cultural mythmaking is emphasised in the British legal research of the early 2000s:

In the myth making about paedophilia, the most enduring cliché of all is the 'dirty old man', usually found hanging around school playgrounds. Given that most offending takes place in the home and that as much as a third is committed by adolescents, this image is already way past its sell by date (Wilson \& Silverman, 2002, p. 57).

Such myth-making and storytelling is crucial in shaping comic representations of CSA, where the set character of the CS abuser is created, projected, told and retold. It is this fiction that seemingly overtakes the legal definition of the abuser in the popular imagination. These myths and monsters shape the culturally agreedupon ideas about how to engage with and identify CSA, with the above extract arguing that the story of CSA, and the real issue of abuse, remain at odds with one another. It is ironic that such characters are often created with the intention of child abuse prevention by making the abuser visible and identifiable, when legal scholarship on the subject has consistently evidenced that this style of storytelling is not only unhelpful and inaccurate, but obscures the reality of incestuous abuse (Mesler, 2016, p.219). Yet, as Michel Foucault emphasises, legality is itself a construct, and the very concept of the guilty criminal is itself crafted along cultural lines, with the real-life criminal becoming absorbed into cultural myth-making (Foucault, 1975, pp. 37, 157, 164, 169). This is the dirty old man story, where real-life events of CS abuse may become modern folklore through figures ranging from the 'creepy' old male film director (such as Roman Polanski) to the exaggerated image of Jimmy Saville.

Cultural narratives of this CS abuser appear in many mediums. However, in this article, particular focus will be given to provocative adult animated comedy, 
a genre often associated with teenage boys, due to its often wilfully controversial content (Marx, 2013, p.179). Here the supporting character 'Herbert the Pervert' from the American adult animation Family Guy (1999-present), which follows the exploits of the Griffin family, offers a revealing example for this comical mythology. Herbert is presented as an elderly, bald, gay, white, male, softly spoken, Zimmer frame clutching neighbour in the Griffin family's suburban neighbourhood. In various plotlines and cutaway gags across the seasons, he pines and preys on young boys, including Chris, the Griffin family's naïve 14-year-old son. Thus, pivoting such threats of sexual violence against children away from the familial home, and towards an exaggerated figure of queer abjection. Such humour towards this deviant figure hinges particularly on physical comedy, with gags as simple as the character being hit by a fast-moving object and falling over.

Within an early $21^{\text {st }}$ century digital context, the enduring image of this comically repulsive dirty old man continues, though he is resituated from the playground and the white, middle class suburbs to the online chatroom. This digitally mediated CS abuser can again be identified in popular culture through adult animation, as illustrated by the darkly comic British series, Monkey Dust's (2003-2005) grotesque 'Chat Room Pervert' character. Though sharing structural elements of the sketch show, a passion for provocation and a suspicion towards "political correctness" (Norris, 2014, p.16. p.91-98), this is a starkly different show to the colourful slapstick style of Family Guy. The short-lived BBC Three animation, crafts a dystopian vision of Blairite Britain, using sites of social anxiety at the time, including, but not limited to CSA, as inspiration for its comic characters (Norris, p. 52, 85). Despite these contextual differences, the comic trope of the dirty old man remains largely the same. Once again, this CS abuser character is drawn as an elderly, bald, white, male, whose story follows him pretending to be a thirteenyear-old boy named Benji in online chat rooms for children. A monster of pitiful perversity, he is shown wheezing and chain smoking in a stained white vest, as he taps on his keyboard with long, hairy, nicotine-stained fingers in his decrepit apartment. The palms of his hands are covered in pus filled boils, he eats rotten food, coughs phlegm onto the computer screen and claims to resemble Justin Timberlake. Such comical incarnations of cultural anxiety, whether in the broad slapstick of Family Guy, or in the grotesquely comic imagery of Monkey Dust, form the necessary foundations for understanding the transference of child abuser images from the public information model of child abuse prevention, towards the self-awareness of an insider audience who seeks to laugh at this creation.

The humorous nature of these representations should be positioned within the rigid understanding of the CS abuser as a whole. As Bergson explains, "every comic character is a type. Inversely, every resemblance to a type has something comic in it" (Bergson, p.91). Thus, the figure of the CS abuser becomes not just a criminal and medical category of perversity but a comic stock character. Aristotle argued that "comedy aims at representing men as worse", and in positioning 
the paedophile as a subhuman creature it is unsurprising that the figure has become a comic trope (Aristotle, trans. by Butcher, 335 BC/2008, p. 5.). Professor F. H. Buckley, developing the comic theories of Aristotle and Bergson, observed that "the machine man of comedy is defined solely by his vice, the principle character is not a whole person but only a caricature, and this invites our laughter" (Buckley, 2005, p.9). This is reflected in examples such as Chat Room Pervert and Hebert the Pervert, who are both named and defined by their deviancy. They do not have a perversion, they are the perversion, and this is what renders them hideously comical. This is reflective of the fact that "there is no satire without a butt who is satirised, no butt without a signal of inferiority, and no signal of inferiority without a normative message" (Buckley, p.11). But however repulsive these comical child predators may be, they are a benign threat. As Aristotle explains:

Comedy is, as we have said, an imitation of characters of a lower type, not, however, in the full sense of the word bad, the ludicrous being merely a subdivision of the ugly. It consists in some defect or ugliness which is not painful or destructive. To take an obvious example, the comic mask is ugly and distorted, but does not imply pain (Aristotle, p.9).

The comic masking of this character is clear in the aged appearance of cartoon characters such as Herbert the Pervert and Chatroom Pervert. But the humorous delight of the ludicrous, ugly and defective child sex predator hinges on the fact that his desires are constantly thwarted. They are not just amusing because they are perverse, they are amusing because they are pathetic. The audience is disgusted by this character's desires and thrilled by the fact that he will never consummate them. Herbert the Pervert is marked by a trembling desperation in his voice. His prey repeatedly eludes him, he falls off ladders when spying on teenage boys, is obsessed with the newspaper boy who never arrives, and pathetically pleads as they slip away from his grasp.

His failure is a running joke to be broadcast to this long running show's youthfully masculinist audience, described by the media researcher, Nick Marx as a demographic of "lost boys" (Marx, p.179). This complements the French sociologist Luc Boltanksi's theory that "black humour" signifies a Nietzschean model of masculinist heroism that stands against a feminised and weak-willed moralism and sentimentality (Boltanksi, 1999, 180-181). Here to laugh at such concerns for children is proof of being against "the common herd of humanity." (Lippitt, 39)

Similarly, humour stems from the Chatroom Pervert's repeated failure to successfully impersonate a teenage boy in both language and image, with his antiquated references and decaying appearance. Whilst, the final joke of Monkey Dust's Chatroom Pervert is that the young girl he has been attempting to groom is in fact another dirty old man. As reoccurring characters, they are comic constants, in accordance with Foucault's theory of perverse implantation (Foucault, 1978, pp. 36-37), and, akin to Tom and Jerry, they cannot truly succeed in their violence, 
as then they would no longer be amusing. However, they cannot be truly stopped in their attempts, as then the sketches would end.

Zupančič identifies the comic character as a functioning delusional, detached from reality but still functioning within reality: "an ego that keeps secretly believing in its own identity even when the circumstances force him to deny it publicly" (Zupančič , 30, 76, 83) In this sense, it not merely the CSA abuser's delusion that it is acceptable to sexually abuse children that renders him comic, but rather the robust devotion to that delusion regardless of outside circumstance, the law, the terrified responses of actual children, that creates the characters own comic internal world. This is the "conjunction of lack and excess" (McGowan, p.13) that creates comedy. After all, "there would be no comedy at all if the subject could transcend its lack or realize its desire." (McGowan, p.23, 24) In short, if Herbert the Pervert fulfils his desires by abusing the teenage boy it falls from comedy to horror. Whilst, if Herbert was to gain a self-awareness beyond his stock type, to realize the socially unacceptable nature of his identity, and the profound trauma such acts would cause, it falls from comedy to tragedy.

We laugh at the paedophile not just because he is a ludicrous loser, but because we are pleased that, for all our faults, we are not this terrible creature. We feel no guilt in the fact that this "laughter assumes an informational asymmetry between wit and butt" because we know the "comic vice" that renders the paedophile funny is also what renders him villainous (Buckley, p.12-13). Laughter does not make us bullies in this context; it proves we're the good guys. Our laughter, free from shame or social responsibility, can be increased even further if we laugh in social groups. The group exists as an affirmation and witness of our position within the charmed circle of acceptable sexuality and society. For, as Freud observed, the art of joking is the act of judging, thus to laugh at the paedophile is to condemn the paedophile (Freud, p.10). The laughter against this butt serves to enforce and affirm our understanding of the moral order. Thus, positioning the genre within the superiority theory of humour that Aristotle originally proposed.

These characters status as Other asserts mass media's role, including but not limited to television comedy, in defining good and evil and distinguishing between the ordinary and the obscene (Silverstone, 2006, p.25, 102, 56-58, 102). As Professor Roger Silverstone explains, "the media trade in otherness, in the spectacular and the visible" (p.47), as such "they speak to, and to a degree determine, practices of inclusion and exclusion. And as such define the boundary of what it is to be human." (p.57) The CSA abuser as comic monster provides a necessary contribution to this conception, cultivating a "narrative of us and them" and "articulation of difference" built through comic aesthetics and affirmed through audience laughter (p.62). This serves as a powerful example of "media's work as boundary work" that exists to "play with difference [the often queer coded CS abuser] and sameness [the nuclear white suburban family]." (p.19) 
Whilst, in translating the paedophile to a singular clown, the role of crimes against children are reduced from a system of structural oppression to an individualistic Other, rendering the audience no longer responsible for such acts and further able to laugh without guilt (75). This is reflective of Silverstone's observation that "our relation to the other, to the stranger, is the principal determinant of our moral worth and our status as human beings." (101)

Such a sensational stranger further reflects what Silverstone identifies as the "proximity and distance" of media which "undermine the expectation of responsibility and reciprocity that action and communication in face-to-face settings conventionally require." (11) For example, if an actor falls over on television you do not have to stifle laughter or ask if they are okay. On a more extreme level, it is unlikely that a bystander witnessing an adult attempting to sexually abuse a child would simply point and laugh, or if someone confesses their experience of rape, the listener would respond with simply laughter. This is not to ignore nervous laughter, but it does gesture to how this discomfort can be retrospectively channelled, and how such veneers of social responsibility can be eliminated through media play.

But as established through the cartoon hijinks of Family Guy and Monkey Dust, we also laugh at the CS abuser because we know he will not succeed, that either good will prevail, or his own perversity (and of course fictional status) will prevent him from actually consummating the act. This is the benign violation theory of comedy, which allows us to engage with this taboo subject through the 'safe space' of joke telling. It is also the context which allows the joke teller and listener to freely switch with and share the position of the CS abuser, so that the "joker enjoys a kind of immunity through the belief that his or her wit represents insight into a different type of consciousness" (Stott, p.10). This illustrates how CSA-themed humour can exist within Freud's theory of tendentious jokes, "whereby the joking form allows the audience to bypass the restrictions of their moral compass and take pleasure in an expression of violence towards others" (Holm, 2016, p.113).

However, given the cross identification and multi-purpose nature of such humour, it is simply not possible to apply such a fixed framework of power to this complex genre, especially given the inherent Othering of the CS abuser in so many of these jokes. Rather, we can develop these earlier theories within humour studies researcher Dr Nicholas Holm's 2016 theory of edge-work, which he defines as humour that confirms the moral boundaries of good taste by transgressing its borders (Holm, p.117). Within this context, we could argue that many cases of provocative CSA-themed humour are inherently anti-paedophilia because they rely on the reactionary wrongness of summoning this deviant subject. Though this begs the troubling question of what pro-CSA themed humour would consist of.

This itself gestures to the symbiotic relationship between the comic and the horrific, after all the figure of the clown is just as likely to appear in a horror movie as it is a comedy. As Zupančič observes, in "the generator of the comic, there is also a considerable, mostly literary corpus of the uncanny," citing machines and 
doubles as two examples of this cross over. (Zupančič, p. 114) The suburban paedophile is uncanny in his status as both an insider (a white, middle-class man) and an outsider (a violent sex criminal who is often coded as queer), this insidious status of both similarity and difference rendering him both frightening and potentially absurd. However, there is not just humour in the paedophile himself, but in the innocent character being mistaken for a paedophile, a mainstay of the mainstream of American sitcoms of the late $20^{\text {th }}$ and early $21^{\text {st }}$ century. Take this comedy of misunderstanding from the wildly popular sitcom Friends (1994-2004):

Ross: How would [your son] like to come with me to the Museum of Natural History after everyone else has left, just the two of us, and he can touch anything he wants?

Mr. Zelner: [looks horrified]

Ross: I just heard it as you must have heard it and that's not good. Let me start again. I'm a palaeontologist, you'll be there with us and the touching refers only to bones... fossils!

-Friends, 'The One Where Estelle Dies' (2004)

In rendering the white American paedophile ubiquitous as a creature of moral panic in non-fiction media, the figure makes for throwaway humour in situations where there is no real threat of violence in fictional comedy. The audience, having now watched ten long seasons of comic hijinks with Ross Geller and his five friends, knows perfectly well that Ross is not a child rapist. Instead, chalking this scene into a long history of awkward interactions for the long-suffering professor, with Ross being shortly mistaken for a sex offender sitting comfortably alongside the time he owned a pet monkey or got stuck in a pair of leather trousers.

As McGowan explains, "if one emphasizes the victim, then one experiences horror, but shifting the focus to the monster can transform the horror into comedy." (McGowan, p.79) Here in the case of figures such as Chatroom Pervert and Herbert the Pervert, we follow not the terrified perspective of a child, but a bumbling clown, falling off high objects in his comic costume. The audience's laughter asserting the character's Otherness, which in cases such as Herbert the Pervert, so often intermingles with violently homophobic tropes of the queer child abuser. Of course, humour and horror, and comedy and tragedy can exist simultaneously, as Vladimir Nabokov's masterwork Lolita vividly illustrates. (Wepler, 2011) But this is not the genre of the sitcom paedophile, a defanged creature of the uncanny, whose function in the 'mistaken for a paedophile' humour of popular sitcoms such as Friends, extend beyond the grotesque body of this criminal figure towards beloved cultural characters of this era of American comic culture.

\section{Who is the Humourless Sexual Violence Survivor and Why Do We Laugh At Them?}

To understand the humour that radiates from the character of the humourless sexual violence survivor, it is imperative to understand pre-existing suspicions and 
criticisms of expressions of gendered psychological distress. This is identified as part of what Boltanski identifies as the "politics of pity" in $18^{\text {th }}$ century Western philosophy (Boltanksi, 1999, p. 100). Citing Jean-Jacques Rousseau, Boltanski considers the horror of "the emptiness of the [performed] tear", which creates a fear for the woman or child who might "manipulate emotions like a tool, clearly to deceive others for [their] own ends" (100). In such a "disturbing possibility of a strategic use of tears" there is an impulse to "search for signs by which genuine tears can be distinguished from strategic tears" (100). Boltanksi argues that such an outlook was continued by Kant in his "suspicion on impulsive, transient and capricious emotions" found in cultures of sentimental femininity (100-101), which lead to a gendering of externalised emotions, where:

[In the mid $18^{\text {th }}$ century] the ability to have and to externalize feelings which hitherto was not marked sexually or may even have been more frequently attributed to men than to women, is qualitatively transformed into a feminine defect (Boltanksi, p. 101).

From a $21^{\text {st }}$ century, feminist perspective, the American writer Leslie Jamison, in her essay 'Grand Unified Theory of Female Pain', defines such an outlook as "a broader disdain for pain that is understood as performed rather than legitimately felt" (Jamison, 2014, p. 190). Such disdain, Jamison argues, serves as an attempt to "draw a boundary between authentic and fabricated pain", a fabrication that she proposes is inherently rooted in misogynistic readings of the victimised subject (Jamison, p. 191). Though Jamison's study is limited to her narrow cultural and social positionality as a white Ivy league educated American woman writing in the mid2010s, her argument proves pertinent to this trope that did indeed re-emerge in the Ivy league campuses in the mid-2010s.

For this preconceived binary between authentic and fabricated pain is relevant when considering the tension between real-life events of abuse and their cultural representations through humour. It is what allows us to laugh freely at this butt, for to return to the words of Aristotle, "the comic mask is ugly and distorted, but does not imply pain" (Aristotle, p. 9). This is a butt that in exaggerated rhetoric performs pain, but does not truly experience it. Whilst, in the theatrics of tragedy the "spectacle of suffering has been seen as a cause of the spectator's pleasure", it is the comical survivor's inability to convincingly emulate real-world pain that renders her so amusing (Boltanski, 1999, p. 21). For if the character of the aged, suburban white male abuser could become aroused by almost anything, the most innocent of interactions turning into an opportunity to assault and abuse, the character of the humourless, white, privileged, young woman survivor could be offended and upset at almost anything, the most innocent of interactions, rendering her the victim of a harrowing assault.

It is this divergence between reality and self-perception which not only renders this character funny, but also permits the audience to laugh at her without guilt. For, much like the gulf between the dirty old man and the legal reality of CSA, the comic cultural trope of the sexual violence survivor is consciously separated 
from the material conditions of race, class, LGBTQ+ identity, disability and nation that renders a person vulnerable to such acts of violence. Instead, media generated panics surrounding the generational entitlement of overeducated and self-obsessed young women take their place in this style of humorous character creation. Much as Boltanksi defines the figure of pity as a site of "unified representation", where "it is that child there who makes us cry, but any other child could do the same", the comically privileged wounded woman is generic and interchangeable (Boltanksi, 1999, p. 12).

However, this analysis is not an attempt to argue that that this subject is infallible, with a rigorous critique of the limits of such identity driven, feminist campus politics being offered in depth by Naomi Klein, whose 1999 chapter 'The Patriarchy Gets Funky: The Triumph of Identity Marketing' emphasised this movement's liberal alignment with the corporatization of both youth culture and the university campus itself (Klein, 2009).

It is especially important to recognise these comic archetypes, when considering the current literature on humour and digital media's failure to recognise preexisting antipathy towards feminised media pertaining to personal trauma expression. Such limited readings are reflected in Angela Nagle's text Kill All Normies (2017), which quickly dismisses such topics as "hysterical", "anti-male", and representative of a "cult of suffering" (Nagle, 2017, pp. 8, 21, 68, 73). Whilst the masculinist online message board 4chan is contextualised by Nagle - who locates their jokemaking within the work of Friedrich Nietzsche, R. D. Laing and Michel Foucault trauma themed, feminine-coded digital culture receives none of this treatment. The 2013 mental health themed American video game Depression Quest by Zoë Quinn, for example, is dismissed with no analysis or in-depth study, with Nagle claiming that "even to a non-gamer like me [it] looked like a terrible game featuring many of the fragility and mental illness-fetishising characteristics of the kind of feminism that has emerged online in recent years" (Nagle, p. 21). Nagle takes a similarly reductive and reactive stance to the issue of trauma management schemes on college campuses, speaking of "young women who had never gone to war claiming to have posttraumatic stress disorder" (Nagle, p. 78).

In the autumn of 1993, over twenty years earlier, American journalism was similarly awash with campus exposes, humorous take downs and passionate think pieces on the sorry state of over sensitive, privileged young American women. This is the argument of the campus as supposedly "so awash in the hysteria of political correctness that it seemed entirely possible a lamppost could commit date rape" (Daum, 2007). Such an outlook is evidenced in the case of the Antioch College's 1991 Sexual Consent Policy, which advocated for affirmative, enthusiastic consent on campus, and "not only came to symbolize the infantilizing dogma of the new left, it turned an already obscure college into a laughingstock" (Daum, 2007). Such a campaign not only affirmed 1990s stereotypes of "shrill, kiss-legislating feminists with shaved heads, ethnic vests, and Doc Martens" (Saltman, 2014), as well as 
broader characterisations of humourless feminist killjoys (Ahmed, 2016, pp. 261-262), it even inspired an entire 1993 Saturday Night Live sketch (Stoeffel, 2014).

Opening with stock footage of a college campus, the Casino Royale theme plays and an enthusiastic voice over booms, "Live, from Antioch College in Antioch, Ohio... it's time to play..." The scene cuts to a classic 20th century all American game show set up, with an enthusiastic audience shouting out the game's title: 'Is it Date Rape?' It's clear that this is a parody of Antioch College's rape prevention policies, with the introduction of "your host, the dean of intergender relations", introducing us to the contestant, and "our defending champion", "a Junior and a major in Victimization Studies", Ariel Helpern-Strauss, played by Shannen Doherty. Ariel's purportedly correct answers to the question of "is it date rape?", including a male student helping a female student to "move a futon" and ordering surf and turf on a date. As The New York Times observed, "The comedy routines almost write themselves' because "Antioch's policy is easy to parody" (Ed., 1993). Everything about this situation is understood to be unfeeling and bizarre, as an insult both to higher learning and sexual pleasure itself, it is understood as an active invitation for mockery. Here the purported unsexiness of verbal consent only emphasises how unintentionally funny such feminist campus campaigns really are. Such comic transformations of anti-violence activism can be understood through arguments of the violent and predatory nature of joke telling itself, with Freud arguing that such humour "transforms the initially indifferent audience [in this case television viewers who may not have had strong feeling in regards to university consent legislation] into accomplices in hate or scorn". (Freud, p. 535)

This humorously humourless butt remerged in academic, comic and journalistic discourses two decades later, through cultural conflicts ranging from trigger warnings, sexual violence survivordom and queer generational frictions in the mid2010s. Given the contentious nature of many of these subjects, and the sheer volume of work published on these debates, it is easy to become consumed in a sea of public opinion. However, this analysis is not an attempt to draw my own defence on these wide-ranging issues, for as emphasised in the work of Klein, these movements are not without valid criticism. Rather, it is my intention to highlight how these debates revealed the enduring significance of the humourless survivor as a comic trope, and then consider this comic figure's connection to wider systems of power.

A revealing example of this comic trope can be found in queer theorist Jack Halberstam's 2014 tongue-in-cheek blog post and polemic 'You are Triggering Me!', published by the queer theory collective Bully Bloggers, with Halberstam positioning young people of the mid-2010s as "the triggered generation" (Halberstam, 2014). Halberstam contrasts this generational group with the 1990 s feminist queer movement the author identifies with, positioning this movement as superior, because they were able "to laugh" and "loosen up". The writer uses Monty Python's classic 'Four Yorkshiremen' sketch as an exaggerated parallel for 'the hardship 
competitions, but without the humour' of social justice oriented students, arguing that we have created a culture of young, queer and feminist identified individuals who are "too vulnerable to take a joke, too damaged to make one". In short, the "trigger warning generation" were afflicted by both a lack of humour and a lack of trauma, and such safeguarding methods were the symptoms of this disorder.

The utilisation of Monty Python in Halberstam's argument is particularly useful for understanding the relationship between humour and the killjoy survivor. By utilising a widely known example from the classic white male British comic canon, the writer's work is positioned on the side of popular patriarchal comic history and within the borders of acceptable humour. This serves as a parallel to a deeper history of appropriating Python humour as cultural capital, lampooned in the UK series The Office (2001-2003) through Ricky Gervais' office manager character, David Brent.

In the episode 'The Quiz' (2001), we watch Brent attempt to solidify his funny man status by naming his office quiz group, after the famous Python sketch, 'The Dead Parrots'. Alongside Brent's references to Morecambe and Wise, Kenneth Williams, and Jim Carey, his application of comic cultural history is reflective of his struggle against Dostoevsky-reading "college boys", whose only real job is "Professor in charge of watching 'Countdown' every day". Brent's humour acts as a performative attempt to solidify power through play against his younger, universityeducated employees who dismiss his knowledge of "old entertainment."

In this sense, to quote Monty Python functions as a form of power play that is reflective of a struggle in both genre and generation. It is such power dynamics in comic consumption which, as the trans feminist theorist and performance artist, Julia Serano argues, may result in a misunderstanding of Monty Python's iconic sketch history. Speaking of Halberstam's utilisation of the 'Four Yorkshiremen' sketch, she notes:

Personally, I always understood that Monty Python sketch as making fun of how people, as they get older, tend to glorify their own past: imagining the hardships they faced as being especially challenging or severe, thereby allowing them to selfconceptualize themselves as being especially resourceful, righteous, cunning, and perseverant for having survived despite overwhelming odds. And this human tendency has historically enabled older generations to outright dismiss younger generations as being misguided, or especially soft (because 'they have it so much easier than we did'), and so on (Serano, 2014).

As illustrated in the case of Antioch college in the 1990s, comic generational conflicts, included but not limited to, the humorous figure of the over-sensitive killjoy were not unique to this time period, and even in Halberstam's own blog post we are reminded of the historical connections to the comical, hysterical feminine grotesque. This is what Halberstam defines as the twentieth-century history of "weepy white lady feminism", which the writer considers a "messy, unappealing morass of weepy, hypoallergic, psychosomatic, anti-sex, anti-fun, anti-porn, prodrama, pro-processing post-political subjects." This figure is one who is too privi- 
leged to deserve a platform to articulate their hardships, and too frigid to lighten up and let it go. Thus, we return to Jamison's idea of performing pain and the comedy that grows from this narrative.

Such criticism of feminine coded trauma through humour can be situated within a wider embrace of comedy against feminist and trauma and mental health advocacy during the early to mid-2010s. "Trigger warning: I'm going to make fun of trigger warnings' opens one Los Angeles Times think piece on the subject" (Goldberg, 2014). Whilst, the animated comedy, The Simpsons dedicated an entire 2017 episode to the "highly entitled wusses" of Yale University, who are reimagined as easily offended red lipstick wearing robots, quite literally exploding with outrage on their Ivy league campus. This genre of humour was wide ranging in authorship, from youthfully masculinist Trump supporters, liberal leaning centrist screen comedy, to senior scholars of Queer theory and pioneering theorists of Marxist media criticism, illustrating the wide reach of this comic figure, who similar to the dirty old man, stands as exaggerated antagonist for a wide range of ills. As the feminist media researcher, Dr Katariina Kyrölä, observes: "Disquietingly, the feminist and anti-feminist critics of trigger warnings often share a humorous and mocking tone. This tone leaves the proponents of trigger warnings with no other role than that of feminist killjoy" (Kyrölä, 2018, p. 45). This echoes McGowan's observation that, "someone who identifies with the suffering of a person who falls cannot laugh at the fall, even if the fall is intended to generate comedy", leaving the feminist anti-violence advocate in a barren landscape free from laughter (McGowan, p. 128).

Such an outlook is powerfully reflected in the Marxist cultural theorist and educator, Mark Fisher's 2013 text 'Exiting the Vampire Castle', which rails against a left wing-identified branch of feminist, digital activism, contrasting the "cool, sexy and proletarian" politically-informed stand up of Russell Brand against their "fingerwagging sermon" (Fisher, 2013). These technologically embedded feminist killjoys, "sour faced", "moralising", "passive aggressive" and "dour", are the "vampires" of Fisher's argument (Fisher, 2013). They are positioned both as humourless, because "the use of humour was what separated Brand from the dourness of so much 'leftism", and as utilising the wrong kind of humour, through their "snarky resentment".

Fisher's criticism of "snark" is crucial to the question of what sort of humour is acceptable in debates surrounding feminism, queer justice and trauma management. For it must be remembered that both Fisher's and Halberstam's pieces on humourless feminists were largely criticised through humour (Garton, 2017). Halberstam's writing even provoked the creation of a parodically humorous Twitter account, 'Jock Halberslam' which follows a Halberstam-ian figure in sunglasses and a back-to-front baseball cap rallying against "whiners" and "kids these days." The account presented an image of a parodically masculinist legacy of queer theory, which favoured abstract theory over the material realities of queer youth. For instance, one humorous tweet reads, "but jock, don't you care about queer kids? 
in the words of my bro lee edelman: fuck the child" ('Jock Halberslam', Twitter, $8^{\text {th }}$ July 2014).

The question here is not whether feminists and queer youth working in trauma advocacy can laugh, but rather how they are laughing, and at who. As feminist researcher Emily R. Douglas explains in her study of digital feminist humour, "there are 'normal' ways to laugh, which vary according to many factors, such as class, race, and gender", itself a further reminder that Ahmed's subject of the Feminist Kill Joy extends far beyond the weepy white ladies that Halberstam evokes (Douglas, 2015, p. 146). This top-down structure of humour creates a system where women particularly LGBTQ+, working-class and Black women - "are not supposed to be creators of humour, inasmuch as this role would ascribe to them power and intellectual qualities denied to them by the majority culture, they are supposed to applaud the humour of that majority culture and, above all, not take themselves too seriously" (Douglas, p. 142).

Whilst, the Python references of Halberstam or the stand-up comedy of white male celebrities such as Russell Brand can be situated within 'normal', canonically approved laughter, feminist, trauma-inflected, digital humour cannot. bell hooks' argument that "we cannot have a meaningful revolution without humour" is made relevant as the question of what is actually considered humour, and for who, is so closely contested (Yancy, 2017, p. 15). Here Fisher's Gothic image of the vampiric cackle of the digital feminist serves as a reminder that whilst the humourless feminist is a site of mockery, the laughing feminist is a figure to fear.

The much-cited Margaret Atwood quotation that "men are afraid of being laughed at" by women whilst women are afraid of "being killed" by men should thus be reconsidered within a comedy studies context (Atwood, 2000, p. 413). On first glance the comparison between 'killed' and 'laughed at' seems to contrast the structural violence of men with the individual harmlessness of women. But it is more useful here to understand how laughter from women towards existing patriarchal structures - included but not limited to individual men - is considered an act of violence in and of itself. As Sara Ahmed, writing on the violence of feminist laughter, explains, "to laugh compulsively, even violently, at gender as reason, is to expose its violence. To expose violence is to become the origin of violence" (Ahmed, pp. 2014-2015). For instance, psychologist Harvey Mindess condemned the "scornful wit" of the women's liberation movement of the 1970s (Mindess, 2011, p. 197). Whilst, in the 2015 case of Bahar Mustafa, the student union welfare and diversity officer at Goldsmiths, whose jokes about killing white men on Twitter resulted in her potentially facing criminal prosecution, "Valerie Solanas style feminist humour on social media" is seen as an act of violence in and of itself (Ahmed, 2015). This reflects Simone de Beauvoir's observations of how the young girl's "scoffing" humour, that "defies adults" and "ridicules men" has the power "to kill" (de Beavoir, 2011, p. 365). Thus, the constructs of both the survivor and of the feminist, as hatefully humorous and frigidly humourless, are integral to our understanding of representations of the sexual violence survivor in the realm of the comic. 
As Serano argues "in activism (as it is with humour), context is everything" (Serano, 2014). Thus, it is worth considering why the safeguarding methods, trigger warnings and safe spaces being lampooned through online humour, were so closely linked to harm prevention for sexual violence survivors (Knox, 2017, p. 29). This is developed by recognising which women's experiences within the LGBTQ+ community are dismissed most forcefully, with Halberstam's comic critique focussing on slurs specifically disenfranchising trans women. Such rejections should also be informed by issues of ableism and disability justice, with issues of disability accessincluding, but not limited to, mental health issues pertaining to trauma, depoliticised to signal selfish, individual preferences rather than systematic neglect. As Kathleen Ann Livingston, argues:

\section{The characterization of who trigger warnings are for - young, white, female, heavily protected, oversensitive, possibly crazy - is a red herring, meant to distract from two purposes of trigger warnings, to provide accommodations and accountability for trauma survivors. The image of the 'over-sensitive' woman denies both the complexities of who students are and the embodied experiences of being a survivor (Livingstone, 2014).}

This gulf between comically whitewashed representations of the survivor, and the material injustices that facilitate real life acts of abuse, parallel the gap between the character of the dirty old man and the reality of CSA. This could not be understood without the scholarship of Black feminist academics, evidenced both in the study of history as evidenced in the work of Professor Angela Davis (Davis, 1983, pp. 172-202), and Professor Patricia Hill Collins (Hill Collins, 2008, pp. 123-149) and the study of law, as shown in the pioneering framework of intersectionality built by the American lawyer and theorist Professor Kimberlé Williams Crenshaw (Crenshaw, 1989, pp. 39-168.) and Professor Priscilla A. Ocen's research into anti-Black constructs of the innocent child victim (Ocen, 2015, pp. 1593, 1594, 1598, 1599, 1607). Far from the whitewashed stereotypes of this comic character, the realities of this violence are inherently tied to the history of racism, particularly anti-Black racism, and colonialism, both within and against feminist movements. Characterised as "wailing, moaning, weeping", "hysterical", "over-reacting, sensitive, easily hurt, angry", the feminist killjoy identified by the feminist and critical race theorist, Sara Ahmed, is a feminist of colour, and it is this erasure that is inherent to understanding the numerous issues behind generalising trauma advocacy under the comic trope of the coddled, wealthy white student (Ahmed, 2017; 2015). This is revelatory of the power of the killjoy, whose mere presence kills the laughter in the room, who is oversensitive because she is "sensitive to that which is not over" (Ahmed, 2004, pp. 224-225; Ahmed, 2010, pp. 66-68; Ahmed, 2014, pp. 2014).

Such comic characters illustrate how the often reactive medium of humour, accelerates Ahmed's warning of queer, feminist identified criticisms of the killjoy, "When you assume your own oppositionality too quickly, you can inflate a minority into a majority, hear an injury as a lobby, interpret a fight for survival as the formation of an industry" (Ahmed, 2014). Here humorous archetypes of sensitive 
snowflakes, whiny white girls and self-righteous students consume real world voices and concerns, at the expense of the women who are most vulnerable to structural issues of abuse, whilst, as the Halberstam and Fisher's cases ironically illustrate, such stereotypes of the humourless feminist are being effectively addressed through digitally mediated humour. Yet, as emphasised by Klein's study into the failures of the 1990s feminist campus activism, this does not mean the original subjects of mockery, such as the application of trigger warnings, are themselves beyond criticism. Neither, does my identification of these comic tropes within the works of pioneering theorists such as Halberstam and Fisher, detract from the value of these writers own rich bodies of work.

\section{Changing Cultures of the Rape Joke Following the Me Too Movement}

As Zupančič argues, "comedy is the universal at work" (Zupančič, p. 27), and it is necessary to consider how the popular comedy of sexual violence has shifted in wake of shifting standards of acceptability in regards to cultures of both consent and comedy. This is particularly notable in the wake of the Me Too movement. Me Too is the viral feminist hashtag through which survivors could share their stories. It was originally created in 2006 as a community-building framework by Senior Director at Girls for Gender Equity, Tarana Burke. This was with the intention of supporting overlooked child sexual abuse (CSA) survivors from marginalised backgrounds, with a particular focus on Black and Brown girls, firstly in her community of Alabama, and then across America.

Me Too then came to prominence in 2017 on Twitter thanks to Hollywood actress Alyssa Milano. Here it became a lens to address the prevalence of sexual violence against women, particularly in the workplace, with the press focussing on industries such as film, television, politics, literature, publishing, sports and music. However, advocacy also addressed medicine, academia, farming, the Christian Church, the military and tattooing. The active Me Too movements extends across the world to countries such as Afghanistan, China, Ethiopia, India, Iran, Japan, Kenya, Macedonia, Mexico, Pakistan, the Philippines, South Korea, Taiwan and Vietnam.

To consider the impact of Me Too through the lens of comedy is not to reduce a global movement, with its roots in combatting the systematic sexual abuse of Black girls, merely to its influence on sitcom jokes. But rather it is to explore how the role of public advocacy may shift the consensus of the comic. This itself simultaneously reflects the parasitic consumption of feminist and anti-racist grassroots movements into what Naomi Klein identifies as a "politics of mirrors and metaphors" under capitalism (Klein, 2009, p. 143), whilst gesturing at the role of comedy as a creative tool in navigating and narrating systems of oppression.

In the early 2010s, the popular feminist consensus on rape humour by feminist critics such as Roxane Gay was that its function was "designed to remind women 
that they are still not quite equal" (Gay, 2012). A point emphasised by the American shock comedian Daniel Tosh, who garnered feminist criticism for his use of rape jokes against women in his own audience during a 2012 stand-up routine. Yet, by the mid-2010s, comedy became intertwined with the pursuit of justice for rape survivors. This shifting viewpoint was exemplified through the American comedian, Hannibal Burress, whose 2014 stand-up routine about Bill Cosby's history of sexual abuse, lead dozens of women to speak out on their own experiences of abuse by Cosby across four decades. Though many of these acts fell outside of the statute of limitations, in 2018 Cosby was found guilty of three counts of aggravated indecent assault. Thus, in 2015, the rape joke was declared "finally funny" by leading feminist essayists such as Rebecca Solnit, who argued that:

\section{Rape jokes are what an evolutionary biologist might call an indicator species. One small part of the ecosystem, such an organism can indicate the larger health or illness of the whole or a system in transition. The culture itself has changed, for the better, in the past three years, in regards to women and consciousness about sexual violence. The evolution of the rape joke marks that change. In 2015, the high- profile jokes are on rapists, the mindsets of rapists, and on rape culture (Solnit, 2015).}

Such an evolution can be found in the development of sexual violence humour in the provocative American sitcom It's Always Sunny in Philadephia (IASIP) (FX: 2005-present). From December 2020, IASIP became the longest running American live action comedy, with television journalist, Stuart Heritage arguing that "the key to Sunny's longevity is arguably its subtle accommodation of shifting tastes" (Heritage, 2021). Such shifting tastes extends beyond jokes surrounding rape and CSA to its comic engagements with broader systems of violence such as anti-Black racism, ableism, transmisogyny and homophobia. For example, whilst the show was populated with crude transmisognistic humour in mid-2000s episodes such as 'Charlie has Cancer' (2005) by the mid-2010s IASIP was critically acclaimed for questions of LGBTQ+ representations through the Season 13 finale, 'Mac Finds his Pride' (2018).

The show, like so much of comedy, deals largely in broad types, with both its central and reoccurring characters relying on a generic category of dysfunction and degeneration. Here we have: Dennis Reynolds, the monster who believes himself to be a "golden god", a potential serial killer and almost certainly serial rapist, Charlie Kelly, the creepy stalker, the illiterate man child and repressed child rape victim, who is closer to an animal living in filth than a functioning adult man, Uncle Jack, the gay paedophile, Ronald 'Mac' McDonald, the repressed gay man, Dee, the failed actress, liberal bigot, spinster and hanger-on, Frank Reynolds, the dinosaur, a fossil of bigotry and crude humour, who symbolises the excesses and evils of the rich, white America patriarch, and finally, Matthew "Rickety Cricket" Mara, the fallen priest, turned desperate, homeless, disfigured, blinded, addict and sex worker. It is a black comedy about cruelty, but as a cultural artefact it is also a portrait of what level of cruel comedy is deemed acceptable and profitable to broadcast to the general public. 
In earlier episodes, such as 'Charlie Got Molested' (2005), 'Sweet Dee's Dating a Ret*rded Person' (2007), 'The Great Recession' (2009) and 'Dennis Gets Divorced' (2010), the dark humour of sexual violence lies in the delusion of either the survivor or the abuser to recognise their abuse. This is illustrated in the figure of Uncle Jack, a moustachioed, breathy gay paedophile archetype, whose humour lies in his sexual desperation to his former CSA victim, the adult Charlie, in contrast to Charlie's blatant repulsion towards him. Take for example a scene from the 2009 episode, 'The Great Recession', where abuser and abused, comically spar about their experiences and traumatic histories:

Uncle Jack: You can share the room with me, Charlie.

Charlie's Mom: [Gasps] That's a great idea!

Charlie: That is not a great idea.

Uncle Jack: Well, why not? It'll be fun. You know, you and me palling around, getting nuts, doing crazy, fun things.

Charlie: I'm not doing any kind of things that you want me to do with you, Uncle Jack.

Uncle Jack: No, it's- it's stuff that relatives do. We'll share the room, Charlie.

Charlie: - I don't want to share the room with you, dude, because I... I will spend the whole night wide awake like when I was a kid and you tried to share my room.

Uncle Jack: You ever seen wrestling on television?

Charlie: I am well aware of what wrestling is. It's just not what uncles do to their nephews.

Such tensions are complemented by comically absurd scenes demonstrating Charlie's own delusion of the acceptability of his own experiences of CSA. For example, in the episode 'Sweet Dee's Dating a Ret*rded Person' (2007), Charlie performs a graphic confession of his assault by Uncle Charlie as an upbeat musical number, to the horror of his peers, whilst dressed as Bob Dylan.

Mac: The first half of that song was kinda cool, but what's with the second half?

Charlie: It's about the Night Man, like, filling me up, and I become him. I become the spirit of the Night Man.

Mac: It sounds like a song where a man breaks into your house and rapes you.

Charlie: What, dude? Where are you getting that from? All right. No.

Whilst both Charlie and Jack are presented as somehow equally pathetic in their state as CS abuser and CSA victim, a more complex portrait of darkly comic abuse in IASIP emerges in the figure of Dennis Reynolds. Described as "arguably one of tv's scarier monsters" (Baessler, 2018), Dennis' status as an abuser is a manifestation of a larger system of power of white, wealthy American patriarchy, which is essential to both his humour and horror. Establishing his pattern of abuse early into the show, claiming that "they [the women he attempts to seduce] can't refuse [his sexual aggression] because of the implication [of danger]" ("The Gang Buys A Boat, 
2010) and that he does not listen to words such as "no," or "don't," or "stop" ('The Aluminium Monster vs. Fatty Magoo', 2007). Reynolds is a figure of wilful manipulation, a creature of vanity, he conceals his own appearance, with makeup to hide his receding hairline and gaunt, haggard features ('Dee Day', 2019). Similarly, his environment is carefully curated to aid his abuse, with his sealed and soundproofed bedroom for his "sexual conquests" ('The Gang Escapes', 2018) and his "tools" of zip ties and duct tape that he keeps in a hidden compartment of his car ('The Highschool Reunion', 2011). Reynolds is an organised and methodical abuser, who owns a vast collection of non-consensual sex tapes, and even has a self-titled D.E.N.N.I.S. system for emotionally abusing women ('The D.E.N.N.I.S. System', 2009).

Thirteen years of character building, alongside the production team's responsiveness to shifting conversations towards sexual violence, culminated in the 2018 episode, 'Times Up For The Gang', a reference to the Time's Up charity that was founded in the wake of the Me Too movement to support victims of sexual harassment. The friendship group are forced to attend a sexual harassment seminar in light of an online 'Shitty Bar List', naming their pub as a hotbed for misconduct. This is a reference to the real-life 'Shitty Media Men' list, a crowd sourced 2017 Google spreadsheet that collected allegations of abuse within New York media. Whilst, Frank, Dee, Charlie and Mac quickly buckle under scrutiny as their histories of rape, abuse, stalking and sexual misconduct are revealed, Dennis remains cool, as he attempts to carefully control and conceal the misogynistic and sexually abusive behaviour of those around him, due to an awareness that "women are on a little bit of a rampage, and anyone could be taken down at any moment now."

He demonstrates an unsettling in-depth knowledge of the minutia of legal history around sexual misconduct, and at the end of the episode takes over from the workshop leaders to give his own presentation on the Time's Up and Me Too movement. Here Dennis details how "I keep my body tight. But I also keep my life tight", sharing his "time-stamped and coded" receipts of "each partner's consent and enjoyment" in a PowerPoint presentation. It is then revealed that it was Dennis himself who created the Shitty Bar List, and subsequently set up the sexual harassment seminar, because "you got to clean up your act. Otherwise, you're going down, and you're gonna take me down with you, and I ain't going down." In a final flourish, the sexual harassment lecturer, on realising she has been hired by a serial rapist who is seeking to protect himself, cries out in horror, "you're a monster!" To which Dennis triumphantly responds, against a ticking clock, a nod to the Time's Up movement, "Oh, yeah? Prove it."

This illustrates Zupančič argument that "the comic universe is, as a rule, the universe of the indestructible" (Zupančič, p. 28) and McGowan's observation that "one of the distinguishing traits of comic characters is their survivability." (McGowan, p. 75) In this sense, Reynolds status as both an unrepentant and uncatchable sex abuser is the key to his comedy. Yet, such claim of survivability and indestructibility similarly applies to the long-running show itself. Despite its use of seemingly bad taste humour, the episode was praised by media critics for 
"[engaging] with sensitive material through the seemingly insensitive satire" (2018, Baessler). Whilst, the fact that the episode was written by Megan Ganz, who experienced her own publicised experience of workplace abuse and sexual harassment, from comedy writer Dan Harmon (Bromwich, 2018), and admits that writing the episode "helped me exorcise a lot of demons in a productive and funny way" (Longo, 2018), further complements the survivor first sensibility that grew from the Me Too movement. This allows a liberal audience to laugh at the unrepentant abuser Dennis without guilt, due to "our [the comic audience's] tendency to look for the political valence of comedy in either who creates the comedy or who is its object" (McGowan, p. 163). Thus, by creating a comic character out of the rapist, with the contextual knowledge of the writer's own experiences, the episode complements Solnit's argument that "the high-profile jokes are on rapists, the mindsets of rapists, and on rape culture."

Yet, I would be hesitant to reduce a genre as multi-directional as comedy, or a show as ambiguous as IASIP to simple claims of empowerment. For a joke can allow multiple identifications, and the identity of authorship is not necessarily the instant explanation of ethical soundness that it appears to be. For example, in my own research into humour and CSA, I have been pressured to share my own experiences of CSA survivordom to allow a reader to feel comfortable reading such uncomfortable subject matter. Similarly, through this reductive and identity-centric lens, my admission that I personally found the humour of Uncle Jack and Charlie funny when my own mental health was particularly poor, might suggest it is somehow a good example of CSA humour. Such neat explanations flatten a person to their experience of interpersonal violence, and neglects to account for broader power systems such as race, class, nation, LGBTQ identity and disability that contribute both to the violence a person experiences, and to how a person's humour is shaped. Rather, I would argue that an emphasis on the survivor as author when determining the moral value of a comic media text hinges on issues of the cultural perimeters of liberal acceptability rather than any meaningful sense of justice for survivors of any form of sexual violence. This itself reflects the fact that a small selection of carceral convictions of high-profile celebrities is not equal to restorative justice for systematic violence of sexual abuse.

\section{Conclusion: Dirty Old Man and Weepy White Girls}

The comic archetypes of the dirty old man and the traumatised young woman has been explored in a select number of close reading examples of British and American screen humour from the 1990s to the 2010s. Though the article is limited by this narrow perimeter, the role of comedy as a dynamic space for negotiating fears and hostilities towards both the figure of the CS abuser and the sexual violence victim within this specific context is revealed. Through humorous character creation ranging from animated comedies, sketch shows and sitcoms, complemented by politically diverse polemics, the multipurpose function of these 
characters are revealed. Both liberal and conservative, a threat to left wing politics, and in the minds of reactionary right-wing pundits, a symptom of its degeneracy, both characters are able to absorb, and deflect a number of social ills. This is achieved through divorcing these comic characters from the material conditions of power such as race, class, disability, LGBTQ+ identity and nation that renders a person vulnerable to sexual violence, and is informed by comic theories of benign violation, edge work and social ordering. Thus, the assertion that subjects as painful as sexual violence are somehow beyond a joke are critically challenged. Instead, the centrality of the study of social power in the theory of comedy is highlighted.

This is understood through centring the media' role in creating such a vivid mythos of sexual deviance and evil through the construction of the Other, as explained by Roger Silverstone. Silverstone's emphasis on the centrality of play in such media projections lends itself well to the genre of sexual violence themed screen humour, and is illustrative of the contentious question of whether humour can be garnered from such acts of violence. Here such media examples as Family Guy, Monkey Dust, Saturday Night Live, and Friends, illustrate that though the genre of screen comedy is indeed central to conceptions of the Othering of sexual violence, whether we choose to laugh at such a character, or instead occupy Ahmed's role of the feminist killjoy is an ethical decision, as much as a nervous impulse.

Here the strange, solitary, often queer coded, figure of the dirty old man has no real position of power, or connection to the outside world beyond his front lawn and desktop computer, and is instead a comic punching bag for humour both slapstick and grotesque. Whilst, the sexual violence survivor becomes a threatening figure of individual privilege rather than a victim of systematic oppression. Both are presented as monstrous in their delusions and desires, but ultimately toothless in their actions. As a result, we are provided with an amusing selection of cartoon characters to insert into a variety of comic set pieces. This Aristotelian wardrobe of comic masks allows us to laugh at this taboo subject with the safety the abuser cannot hurt anyone, and that the victim's pain is not genuinely felt. Despite the wide varying styles of humour, politics, social contexts and creative mediums these characters have been presented in over the years, the trope for many decades remained largely unchanged. For these characters do not subvert, but rather enforce existing boundaries of criminality, and serve as a reminder that social engagements with sexual violence extend beyond judge and jury, and abuser and victim, in order to be found in a vast range of genres both serious and silly. However, the example of It's Always Sunny in Philadelphia gestures towards shifts in popular comic tastes in the wake of the Me Too movement, whilst Ahmed's own studies into feminist laughter gestures at the medium's radical potential for survivors themselves to destabilise systems of injustice through humour. 


\section{References / Список литературы}

Ahmed, S. (2004). The Cultural Politics of Emotion. New York: Routledge.

Ahmed, S. (2010). The Promise of Happiness. North Carolina: Duke University Press.

Ahmed, S. (2014a). Wilful subjects. Durham, North Carolina: Duke University Press.

Ahmed, S. (2014b, July 21). Feminist Hurt/Feminism Hurts'. Retrieved from Feministkilljoys website: https://feministkilljoys.com/2014/07/21/feminist-hurtfeminism-hurts/

Ahmed, S. (2014c, August 28). A Killjoy in Crisis'. Retrieved from Feministkilljoys website: https://feministkilljoys.com/2014/08/28/a-killjoy-in-crisis/

Ahmed, S. (2015a, May 26). A Campaign of Harassment'. Retrieved from Feministkilljoys website: https://feministkilljoys.com/2015/05/26/a-campaign-of-harassment/

Ahmed, S. (2015b, June 25). Against Students'. Retrieved from Feministkilljoys website: https://feministkilljoys.com/2015/06/25/against-students/

Ahmed, S. (2016). Living a Feminist Life. Durham: Duke University Press.

Ahmed, S. (2017, December 19). Diversity Work as Complaint'. Retrieved from Feministkilljoys website: https://feministkilljoys.com/2017/12/19/diversity-work-as-complaint/

Aristotle. (2008). Poetics (S. H. Butcher, Trans.). New York: Cosimo.

'Ask First' at Antioch'. (1993, October 11). The New York Times. Retrieved from https://www.nytimes.com/1993/10/11/opinion/ask-first-at-antioch.html

Atwood, M. (2000). Second Words: Selected Critical Prose, 1960-1982. Toronto: Anansi.

Baesller, L. (2018). 'Time's Up for the Gang' Is the Perfect Satire of a Delicate Issue. Retrieved from Film School Rejects website: https://filmschoolrejects.com/always-sunny-times-up/

Beauvoir, S. (2011). The Second Sex. New York: Vintage.

Bergson, H. (1911). Laughter (F. Rothwell \& C. Brereton, Trans.). Worcestershire: Read Books Ltd.

Boltanksi, L. (1999). Distant Suffering: Morality, Media and Politics. Cambridge: Cambridge University Press.

Bromwich, J. E. (2018, June 13). Megan Ganz on Dan Harmon's Apology: 'I Felt Vindicated". The New York Times. Retrieved from https://www.nytimes.com/2018/01/13/arts/dan-harmonmegan-ganz.html

Buckley, F. H. (2005). The Morality of Laughter. Michigan: University of Michigan Press.

Chatmon, p. (2019). Dee Day. In I.A.S.I.p. USA: FX.

Coiro, K. (2018). Times Up For The Gang. In I.A.S.I.p. USA: FX.

Crenshaw, K. (1989). Demarginalizing the intersection of race and sex: A Black feminist critique of antidiscrimination doctrine, feminist theory and antiracist politics. In University of Chicago Legal Forum (pp. 139-168). University of Chicago Law School.

Daum, M. (2007, June 30). Who killed Antioch? Womyn'. Los Angeles Times. Retrieved from https://www.latimes.com/la-oe-daum30jun30-column.html

Davis, A. (1983). Women, Race \& Class. New York: Vintage.

Douglas, E. R. (2015). Foucault, Laughter, and Gendered Normalization'. Foucault Studies, (20), 142-154. doi: 10.22439/fs.vOi0.4934 
Einhorn, R. (2009). The D.E.N.N.I.S. System. In I.A.S.I.p. USA: FX.

Einhorn, R. (2010a). Dennis Gets Divorced. In I.A.S.I.p. USA: FX.

Einhorn, R. (2010b). The Gang Buys A Boat. In I.A.S.I.p. USA: FX.

Fisher, M. (2013, November 24). Exiting the Vampire Castle'. Retrieved from Open Democracy website: https://www.opendemocracy.net/en/opendemocracyuk/exiting-vampire-castle/

Fortenberry, J. (2005). Charlie Got Molested. In It's Always Sunny in Philadelphia. USA: FX.

Foucault, M. (1975). Discipline and Punish. New York: Vintage Books.

Foucault, M. (1978). The History of Sexuality (Vol. 1; R. Hurley, Trans.). New York: Pantheon.

Frantz Parsons, E. (2005). Midnight Rangers: Costume and Performance in the Reconstruction-Era Ku Klux Klan'. The Journal of American History, 92(3), 811-836. doi: 10.2307/3659969

Freud, S. (1905). The Standard Edition of the Complete Psychological Works of Sigmund Freud: Jokes and Their Relation to the Unconscious (J. Strachey, Trans.). London: Vintage.

Garton, V. (2017, January 16). Mark Fisher and the Fading of the Left' [The Cyclonograph]. Retrieved from https://vincentgarton.com/2017/01/16/mark-fisher-and-the-fading-of-the-left/

Gay, R. (2012, June 12). Daniel Tosh and rape jokes: Still not funny'. Retrieved from Salon website: https://www.salon.com/2012/07/12/daniel tosh_and rape jokes_still_not funny/

Gervais, R., \& Merchant, S. (2001). The Quiz. In The Office. UK: BBC.

Goldberg, J. (2014, May 19). The Peculiar Madness of "Trigger Warnings". Los Angeles Times. Retrieved from https://www.latimes.com/opinion/op-ed/la-oe-goldberg-trigger-warnings-20140520column.html

Halberstam, J. (2014, July 5). You are Triggering Me!'. Retrieved from Bully Bloggers website: https://bullybloggers.wordpress.com/2014/07/05/you-are-triggering-me-the-neo-liberalrhetoric-of-harm-danger-and-trauma/

Halvorson, G. (2004). The One Where Estelle Dies. In Friends. USA: NBC.

Heritage, S. (2021, February 16). Always Sunny's Glenn Howerton: 'The characters can be horrible misogynists, we the writers are not'. The Guardian. Retrieved from https://www.theguardian.com/tv-and-radio/2021/feb/16/always-sunny-glenn-howertonap-bio

Hill Collins, p. (2000). Black Feminist Thought. Abingdon/New York: Routledge.

Holm, N. (2016). Humour as edge-work: Aesthetics, joke-work and tendentiousness in Tosh.0 (or Daniel Tosh and the mystery of the missing joke-work). Comedy Studies, 7(1), 108-121. doi: 10.1080/2040610X.2016.1146438

Jamison, L. (2015). Empathy Exams. London: Granta.

Jeong, E., \& Lee, J. (2018). We take the red pill, we confront the DickTrix: Online feminist activism and the augmentation of gendered realities in South Korea. Feminist Media Studies, 18(4), 705-717. doi: 10.1080/14680777.2018.1447354

Jock Halberslam'. (2014, July 8). Retrieved from Twitter website: https://twitter.com/halberslam/status/486691553142771712

Klein, N. (2009). No Logo. London: Picador. 
Knox, E. J. M. (2017). Trigger Warnings: History, Theory, Context. Lanham, Maryland: Rowman \& Littlefield.

Kramer, L. (2017). The Caper Chase. In The Simpsons. USA: Fox.

Krefting, R. (2014). All Joking Aside: American Humor and Its Discontents. Maryland: JHU.

Kyrölä, K. (2018). Negotiating Vulnerability in The Trigger Warning Debates. In A. Koivunen, K. Kyrölä, \& I. Ryberg (Eds.), The Power of Vulnerability: Mobilising affect in feminist, queer and antiracist media cultures (pp. 29-50). Manchester: Manchester University Press.

Legman, G. (1968). Rationale of the Dirty Joke: An Analysis of Sexual Humour. New York: Simon \& Schuster.

Levine, J. (2007). Sweet Dee's Dating a Ret*rded Person'. In I.A.S.I.p. USA: FX.

Lippitt, J. (1992). Nietzsche, Zarathustra and The Status Of Laughter'. The British Journal of Aesthetics, 32(1), 39-49. doi: 10.1093/bjaesthetics/32.1.39

Livingston, K. A. (2014). On Rage, Shame, "Realness," and Accountability to Survivors'. Harlot, (12). Retrieved from http://harlotofthearts.org/index.php/harlot/article/view/237/156

Lockyer, S., \& Pickering, M. (2010). You Must be Joking: The Sociological Critique of Humour and Comic Media. In M. Pickering (Ed.), Popular Culture (Vols 1-4, pp. 808-820). California: SAGE.

Longo, C. (2018, September 14). Always Sunny: How The Gang Escaped And Dee Got Her Moment. Retrieved from Den Of Geek website: https://www.denofgeek.com/tv/always-sunny-howthe-gang-escaped-and-dee-got-her-moment/

Lp. (2018). The Gang Escapes. In I.A.S.I.p. USA: FX.

Marx, N. (2013). Family Guy: Undermining Satire'. In E. Thompson \& J. Mittell (Eds.), How to Watch Television (pp. 177-185). New York: NYU Press.

McGowan, T. (2017). Only A Joke Can Save Us: A Theory of Comedy. Evanston: Northwestern University Press.

Medjesky, C. A. (2016). How Can Rape Be Funny? Comic Persona and the Limits of Rape Jokes. In M. R. Meier \& C. R. Schmitt (Eds.), Standing Up, Speaking Out: Stand-Up Comedy and the Rhetoric of Social Change (pp. 195-212). New York: Taylor \& Francis.

Mesler, L., Anderson, G., \& Calkins, C. (2016). Sex Offender Policy and Protection. In M. K. Miller \& B. H. Bornstein (Eds.), Advances in Psychology and Law (Vol. 1, pp. 217-248). New York: Springer.

Mindess, H. (2011). Laughter and Liberation. Abingdon/New York: Routledge.

Morreall, J. (2009). Comic Relief: A Comprehensive Philosophy of Humor. New Jersey: WileyBlackwell.

Nagle, A. (2017). Kill all Normies. Alresford: Zero Books.

Norris, V. (2014). British Television Animation 1997-2010. Hampshire: Palgrave Macmillan.

Ocen, p. A. (2015). (E)Racing Childhood: Examining the Racialized Construction of Childhood and Innocence in the Treatment of Sexually Exploited Minors. UCLA Law Review, 62(6), 1586-1640.

Porochista khakpour. (2018, February 4). Retrieved from Twitter website: https://twitter.com/PKhakpour/status/960219462342291456

Saltman, B. (2014). We Started the Crusade for Affirmative Consent Way Back in the '90s. Retrieved from The Cut website: https://www.thecut.com/2014/10/we-fought-for-affirmativeconsent-in-the-90s.html 
Sartre, J. p. (1948). Anti-Semite and the Jew: An Exploration of the Etiology of Hate. New York: Shocken.

Savage, F. (2007). The Aluminum Monster vs. Fatty Magoo. In I.A.S.I.p. USA: FX.

Savage, F. (2009). The Great Recession. In I.A.S.I.p. USA: FX.

Serano, J. (2014, July 13). Regarding “Generation Wars": Some Reflections Upon Reading the Recent Jack Halberstam Essay. Retrieved from Whipping Girl website:

http://juliaserano.blogspot.co.uk/2014/07/regarding-generation-wars-some.html

Shakman, M. (2011). The Highschool Reunion. In I.A.S.I.p. USA: FX.

Solnit, R. (2015). If rape jokes are finally funny it's because they're targeting rape culture. The Guardian. Retrieved from https://www.theguardian.com/commentisfree/2015/aug/10/jokes-finallyfunny-because-culture-at-the-butt-of-them

Stoeffel, K. (2014). Why the Campus Rape Debate Feels Like a Bad Rerun. Retrieved from https://www.thecut.com/2014/07/campus-rape-debate-feels-like-groundhog-day.html

Stott, A. (2014). Comedy. New York/Abingdon: Routledge.

Thompson, E. (2016). Tosh.0 Convergence Comedy, and the "Post PC" TV Trickster. In C. Bucaria \& L. Barra (Eds.), Taboo Comedy: Television and Controversial Humour. London/New York: Palgrave Macmillan.

Wepler, R. (2011). Nabokov's Nomadic Humor: Lolita. College Literature, 38(4), 76-97. doi: 10.1353/ lit.2011.0045

Wilson, D. (1993). Shannen Doherty/Cypress Hill. In Saturday Night Live. USA: NBC.

Wilson, D., \& Silverman, I. (2002). Innocence Betrayed: Paedophilia, the Media and Society. Cambridge: Polity.

Yancy, G. (2017). On Race: 34 Conversations in a Time of Crisis. Oxford: Oxford University Press.

Zupančič, A. (2008). The Odd One In: On Comedy. Cambridge: Massachusetts Institute of Technology. 